OPEN ACCESS
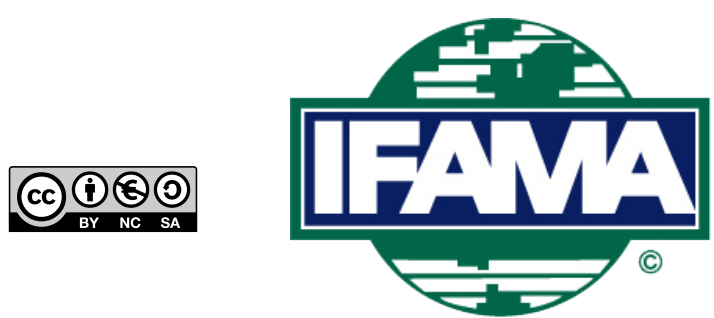

International Food and Agribusiness Management Review

Volume 22 Issue 5, 2019; DOI: 10.22434/IFAMR2018.0093

Received: 20 August 2018 / Accepted: 24 June 2019

\title{
Effect of private-led contract farming on rice growers' yield, cost, selling price and return: evidence from Vietnam's central Mekong Delta \\ RESEARCH ARTICLE
}

Tran Quoc Nhan

PhD and Lecturer, College of Rural Development, Can Tho University, Hoa An Campus, 61 National Road, Phung Hiep District, Hau Giang province, Vietnam

\begin{abstract}
This study attempts to examine the effects of contract farming on rice growers' productivity and profitability in terms of yield, cost, selling price and return in Vietnam's Mekong Delta using different propensity-score matching techniques. By using cross-sectional data collected from 166 rice farmers located in the central Delta, the findings reveal that participation in a contract scheme has a robust positive significant effect on rice farmers' output price and return but has no impact on yield and variable cost. The results of this study suggest that contract farming led by export enterprise enables rice farmers to raise their output price and profitability, which may magnify their household income.
\end{abstract}

Keywords: contract farming, impact, outcome, propensity score matching, rice JEL code: L14, Q13, Q18

Corresponding author: tqnhan@ctu.edu.vn 


\section{Introduction}

The Mekong Delta is considered the 'rice bowl' of Vietnam. Its planted area of paddy and rice production constitute more than $55 \%$ and $56 \%$ of the whole country's total rice grown area and rice production, respectively (GSO, 2016), although this region occupies only $12 \%$ of the total national area. Thus, rice cultivation in the Delta is an extremely important economic sector for both national and farming household economies, supplying more than $90 \%$ of rice export volumes of the country and contributing to 60 to $70 \%$ of farming households' income (GSO, 2016). As a result of its farmers' considerable efforts, Vietnam (as a net importer of rice before 1989) has become the third-largest rice exporter in the world, accounting for approximately $18 \%$ of the world's market share (FAO, 2016). However, almost all rice produced in this region (93\%), is collected from a large number of individual rice households by numerous small-scale collectors (Loc and Son, 2011), due to small-farm scale and lack of vertical coordination. This process seems to result in the mixing of different rice varieties with different quality, causing difficulties in managing the rice quality (Nhan and Yutaka, 2017).

As one of the major efforts of the Government of Vietnam to solve this problem, contract farming has been promoted for use in agriculture, particularly in the rice sector since the Vietnamese government's policy decision No. 80/2002/QD-TTg promulgated in 2002, which was amended by decision No. 62/2013/QD-TTg (2013). This policy seemingly provides strong incentive and support to those who participate in a contract scheme. Specifically, farmers who engage in rice contract farming can access to bank loans at a low interest rate and receive priority to access public extension services. Meanwhile, companies conducting contract farming in the rice sector also get some benefits (e.g. preferential loans from banks, assignment of riceexport by the Vietnam Food Association and priority approval for rice-export by the Vietnamese Ministry of Trade and Industry). Indeed, contract farming is seen as an institutional measure to ensure the quantity and quality of raw materials for processors, distributors, supermarkets and exporters (Reardon et al., 2009; Swinnen and Maertens, 2007). Moreover, contract farming is also considered a promising solution to major constraints of small-scale farmers such as access to inputs, financial capacity, technical capacity, price information, and market outlets at harvest (Barrett et al., 2012; Miyata et al., 2009; Swinnen and Maertens, 2007). Contract firm often provides seed, fertilizer, and other inputs on credit, technical instructions and a guarantee of output price (Eaton and Shepherd, 2001). The growth of high value agriculture, the increase in agricultural processing, the consolidation in retail food outlets, and the high demand for quality and food safety are generally increasing the need for vertical coordination in supply chains (Da Silva, 2005; Jaffee, 2003; Gulati et al., 2007).

More interestingly, the impact of contract farming in developing countries has been a long debate (Glover, 1990; Minot, 1986; Minot and Sawyer, 2016). Some empirical evidences argued that contract farming operated in several cases had negative effects on the participants. By examining the benefits of contract farming through seven case studies in sub-Sahara Africa, Little and Watts (1994) focused on conflicts between farmers and the contract firms, the imbalance of power between the two contracting parties, intrahousehold tensions over labor division and allocation of new revenue, and increasing rural inequality. Porter and Phillips-Howard (1997) reviewing the experience in contract farming in Africa concluded that although contract farming generally raised participants incomes, it caused a majority of social problems. With a case of contract vegetable production in India, Singh (2002) found that contract farming could cause an increase in social inequalities in a community and create conflicts between contract and non-contract farmers. Contract farming may also cause a negative effect on participants' incomes owing to a monopsony and opportunistic behavior of the contract firm, un-transparency of pricing and quality control (Eaton and Shepherd, 2001).

However, numerous earlier studies found the positive effects of contract farming on household income or crop income using various econometric approaches such as instrumental variable model, Heckman selection model, switching regression analysis, and propensity score matching. A large number of those studies show that adoption of contract farming results in higher levels of income (Bellemare, 2012; Birthal et al., 2008; Bolwig et al., 2009; Cahyadi and Waibel, 2013; Hu, 2013; Jones and Gibbon, 2011; Naryananan, 
2014; Maertens and Swinnen, 2009; Maertens and Velde, 2017; Miyata et al., 2009; Wainaina et al., 2014; Warning and Key, 2002). Overall, these studies mostly examined high-value products including industrial and horticultural crops, poultry and dairy sectors but rarely staple foods. This creates a considerable gap on the effects of contract farming in staple crops on farmers' incomes (Maertens and Velde, 2017).

Studies on contract farming are also increasingly growing in Vietnam, such as those by Oanh et al. (2016), Wang et al. (2014), Trifkovíc (2014), Saenger et al. (2013), and Tuan (2012), but these authors mainly placed emphasis on vegetables and industrial crops, catfish and dairy sectors. Besides, it was also found several studies related to rice contract farming in the Mekong Delta. A study by Nhan and Yutaka (2018) explored factors affecting rice farmers' participation in a contract scheme. Nhan and Yutaka (2017) also investigated the constraints of contract enforcement in the rice sector. Dung and Nam (2015) compared production cost and return of rice farming with and without contract scheme. A study by Vinh and Dinh (2014) evaluated the performance of contract integration in production-distribution of rice and proposed some solutions for its development. To best of our knowledge, there is currently no existing evidence on estimating effects of contract farming on both outcomes of rice crop and households in the Mekong Delta although contract farming in the rice sector has been promoted for wide-scale use there since the 2000s (Can, 2014).

Hence, in an effort to document some evidences on outcome effect of contract farming in the rice sector, this study sheds light on the impact of contract farming on Vietnamese rice farmers' outcomes (such as yield, cost, output price and return). By using a cross-sectional data collected from 166 rice farmers in Can Tho City, the central Mekong Delta and employing a propensity score matching approach, the present study aims to examine the impact of contract farming in the rice sector on yield, cost, price and return. Results from the effect of private-led contract farming in rice on these outcome variables are considerably important to help understand how the government's policy on contract farming interact with rice household's welfare. The current study also attempts to contribute significantly to fill the gap in the empirical literature that contains little evidence showing the effect of contract scheme on staple crops, particularly on the rice sector.

The remainder of this paper is structured as follows. The following section describes data and results of descriptive statistics. Section 3 presents the econometric approach, Section 4 presents and discusses the main results of the study and the last section summarizes the findings and proposes policy recommendations.

\section{Data and descriptive statistics}

In order to estimate the effect of participation in contract farming on the productivity and profitability of rice growers, a survey was conducted in September 2017 in Can Tho City of the central Mekong Delta where there are several firms specializing in rice processing and export. The data collection was conducted in Co Do district, recognized as the largest rice-producing district of this City in terms of area and production, where rice export firms presently conduct contract farming and rice production is the most common as compared to other districts. The practice of rice contract farming is still limited and a large number of rice farmers in the study area do not participate in a contract scheme. Consequently, a total of 166 rice growers were interviewed in which 70 interviewees had participated in a contract scheme, while the rest had never participated in contract schemes. Contract and noncontract respondents were randomly selected - the former from lists provided by contract enterprises, the latter from lists provided by hamlet leaders. Importantly, both groups of farmers reside and practice their rice farming in the same geographic area, which ensures the homogeneity of their natural conditions, traffic infrastructure and cultural status. A structured questionnaire covering various questions was used to gather detailed household-level data: demographic characteristics, participation in farmer-based organizations, landholdings, farm asset ownerships, income sources, rice production (family and hired labors, inputs use, input and output prices, inputs supplier, output volume, and outlet). For contract farmers, they were also questioned about contractual details. It should be noted that the questionnaire was tested to adjust the questions before conducting household interviews. Two enterprises that contracted farmers in the sample were also interviewed to gather basic information on their rice business. 
Table 1 presents the main characteristics of the two enterprises that contracted farmers in the sample. Both rice business enterprises are private and domestically owned, and specialize in rice processing and export. Notably, market destination of these enterprises is mainly export market, ranging from 82 to $94 \%$ of their total sales. Therefore, their procurement is mostly conducted under contractual arrangements, which help them to ensure the quality of input purchased from rice growers. The results in the Table 1 show that one enterprise makes $100 \%$ of its procurement from contract farmers; the other one also purchases $80 \%$ of their total input through the contract system. The two enterprises have operated contract farming scheme in the study area for approximately 6 years.

Regarding the process of establishing a contract farming agreement, generally the enterprise first approaches the local authorities for their potential locations where they can conduct contract farming. Secondly, after identifying the location with the local authorities' support, the enterprise holds an orientation workshop on contract scheme for rice growers who may participate in the contract scheme. Based on information from the meeting, rice farmers make decision whether to partake or not in the contract scheme. Interestingly, both enterprises accept all rice farmers who register to engage in the scheme, even if their rice area is small. Finally, the enterprise and individual farmers sign a written contract before rice is grown.

In the survey, only one type of contract was appeared as a directly established contract between the enterprise and rice growers, and in all cases the contracts were written contracts. The contract specifies the varieties, planted area, anticipated output volume, output quality standards, pricing mechanism and use of agrochemical. The enterprise commits to purchasing the entire output from the contract farmers and transport it to its facility. Similarly, contract growers also commit to following all contract terms and selling their output to their contract enterprise. Importantly, the enterprise provides the seed rice to all its contract farmers but pesticide and fertilizer may not be included. In other words, contract farmers must use seed rice provided by the enterprise, but may not use pesticide and fertilizer from it. The enterprise deducts costs of seed and other farming inputs from paddy sales after harvest. Yet contract farmers must adhere to the enterprise's guidelines on agrochemical use (e.g. certain kinds of agrochemicals are not allowed or prohibited), which enables the enterprise to ensure the quality of rice purchased from its contract farmers. Technical training 3-4 times a crop is also delivered to contract farmers and market price plus a premium is often offered by the enterprise. Notably, the fact is that if one party violates the contract, it must take responsibility to compensate the other side as mentioned in the contract terms. More interestingly, leaders of the contract-farmer groups who play a major role in organizing inputs distribution, harvest collection and monitoring of contractual

Table 1. Characteristics of rice business firms.

\begin{tabular}{lll}
\hline Variables & Vinacam-Codo firm & Trung Thanh firm \\
\hline Ownership & Domestically private & $\begin{array}{l}\text { Domestically private } \\
\text { Product }\end{array}$ \\
$\begin{array}{l}\text { Procurement (\%) } \\
\quad \text { Contract farmers }\end{array}$ & \\
$\quad 100$ & 80 \\
$\quad$ Spot market & & 20 \\
Sales (\%) & 70 & 70 \\
$\quad$ Direct export & 24 & 12 \\
$\quad$ Indirect export & 6 & 18 \\
$\quad$ Domestic & 2013 & 2012 \\
Year starts contracting with farmers & 100 & 100 \\
Share of contract farmers receiving inputs (\%) & 0 & 11.4 \\
$\quad+$ Seed & Market price plus premium & Market price plus premium \\
$\quad$ Fertilizer and pesticides & & \\
Determination of price &
\end{tabular}


operation, and these leaders are paid commission fee for their tasks based on the amount of rice purchased from contract farmers by the enterprise.

Table 2 shows the mean values of the socioeconomic characteristics of participants and nonparticipants in a contract scheme. Evidence from the results suggest that participants seem to have better human capital compared with non-participants. Specifically, the head of the household of participants was older and had more experience with rice farming than nonparticipants had. Farmers in the sample had more than 25 -years of rice-farming experience, implying that they have involved in this crop about half of their lives. Additionally, contract households had a larger family size compared with nonparticipants. Nevertheless, the educational background of contract-household head was likely better, but the difference was not significant. With respect to physical capital, rice land area in the survey was somewhat large, with a mean of approximately $2.2 \mathrm{ha}$ per a rice-based farming household when compared to an average rice-land size of a farming household in the Delta around 1.2 ha (GSO, 2017). Contract participants tended to own slightly smaller area of rice land compared with nonparticipants (significant at 0.1 ). The survey also indicated that approximately $60 \%$ of sampled households had a boat, which is the major means of transport for inputs in the study area. However, it was observed that the share of sampled farmers owning agricultural assets in terms of storage, tractor and combine harvester was fairly small, which suggest that farming assets of rice farmers in the study area are limited. The primary source of income for both groups is mostly from rice production. The survey showed that rice income contributes to more than $90 \%$ of the sampled households' income, implying that the aggregate income of sampled farmers is mostly dependent on their rice cultivation. Social participation or membership in farmers' organizations (e.g. agricultural cooperative, cooperative group and extension club) may play an important role in improving farmers' social capital. The number of sampled farmers being a member of such organizations was relatively small; however, contract farmers engaged in these organizations at a higher rate than others did.

Table 2. Summary of descriptive statistics. ${ }^{1}$

\begin{tabular}{|c|c|c|c|c|}
\hline Variable & $\begin{array}{l}\text { Total } \\
\text { sample }\end{array}$ & $\begin{array}{l}\text { Contract } \\
\text { growers }\end{array}$ & $\begin{array}{l}\text { Noncontract } \\
\text { growers }\end{array}$ & $\begin{array}{l}\boldsymbol{t} \text {-test of } \\
\text { difference }\end{array}$ \\
\hline \multicolumn{5}{|l|}{ Household and farm characteristics } \\
\hline Age of household head (years) & 50.124 & 52.429 & 48.438 & ** \\
\hline Farming experience (years) & 25.254 & 27.400 & 23.688 & $* *$ \\
\hline Education of head (years of schooling) & 6.340 & 6.714 & 6.063 & \\
\hline Household size (persons) & 4.590 & 4.871 & 4.385 & ** \\
\hline Rice land area (ha) & 2.190 & 1.913 & 2.388 & $*$ \\
\hline Boat ownership (yes $=1$, otherwise $=0$ ) & 0.580 & 0.571 & 0.583 & \\
\hline Storage ownership (dummy) & 0.040 & 0.014 & 0.063 & \\
\hline Harvester ownership $($ yes $=1$, otherwise $=0$ ) & 0.011 & 0.010 & 0.014 & \\
\hline Tractor ownership $($ yes $=1$, otherwise $=0)$ & 0.043 & 0.029 & 0.052 & \\
\hline Social participation $($ yes $=1$, otherwise $=0$ ) & 0.232 & 0.300 & 0.177 & $*$ \\
\hline Share of rice income per household (\%) & 90.360 & 88.490 & 91.780 & \\
\hline \multicolumn{5}{|l|}{ Rice production estimated for one crop $^{2}$} \\
\hline Production cost (USD per ha) & 817.244 & 804.933 & 826.177 & * \\
\hline Yield (kg per ha) & 7,482 & 7,632 & 7,372 & $*$ \\
\hline Output price (USD per ton) & 231.733 & 233.622 & 230.666 & \\
\hline Revenue (USD per ha) & $1,738.871$ & $1,769.334$ & $1,716.659$ & \\
\hline Average return (USD per ha) & 924.266 & 974.622 & 887.555 & $* *$ \\
\hline
\end{tabular}


Table 2 also displays the summary of a simple cost-benefit analysis for one hectare per one rice-cropping season in the study area. It excluded the fixed costs of agricultural assets in estimating production cost because they are long-term assets and few farmers own them. Consequently, it mainly used variable cost (e.g. costs of seed, fertilizer, pesticide, labor, machinery and fuel) to calculate production cost and return of rice farming with and without a contract scheme. As a result, the average return or profitability was estimated as gross margin obtained for one hectare, which is the mean difference between revenue and variable cost.

\section{Econometric approach}

\subsection{Model specification}

To estimate the outcome effects of participation in contract farming, regression and matching techniques are normally used to correct the selection bias that may result from stakeholders' decision and output (Jalan and Ravallion, 2003; Maertens and Swinnen, 2009). Selection bias due to association between observable covariates and household adoption may be solved either by matching techniques or by including these variables in the regression analysis model (Aakvik, 2001). This study used matching techniques on propensity score to reveal whether contract participant is associated with increases of yield, cost, output price and return.

Caliendo and Kopeinig (2008) reported that it is not possible to observe both outcomes with and without treatment for the same individual at the same time. Yet using the average outcome of non-participants as an approximation is unlikely to be recommended because participants and non-participants may differ substantially even in the absence of treatment, which is known as the so-called selection bias. As earlier mentioned, rice farmers who participated in a contract farming scheme were not randomly assigned (non-experimental), but they are more likely to rely on household self-selection, which may rely on their individual socioeconomic characteristics. Consequently, the impact of selection bias should be considered when estimating the effect of contract farming on rice farmers' outcomes (yield, cost, price and return, in this study).

By taking rice growers who participated in a contract scheme as a treatment group, while other farmers who had never entered into the contract scheme as a control group, the average treatment effect on the treated (ATT) can be estimated using propensity score matching (PSM) developed by Rosenbaum and Rubin (1983). The ATT can be defined as the mean difference between expected outcome values with and without treatment for those who actually participated in the treatment (Caliendo and Kopeinig, 2008). More specifically, it can be assumed that there are two expected outcomes, $\mathrm{Y}_{0}$ and $\mathrm{Y}_{1}$. $\mathrm{Y}_{1}$ demotes the outcome of a household that engages the contract scheme and $\mathrm{Y}_{0}$ is the outcome for this household if it did not engage the contract scheme. The fact that a farmer can only either participate or not participate in the contract scheme simultaneously, suggest that there is only one expected outcome observed. Therefore, the average effect of participation in a contract scheme on contract farmers' outcomes (yield, cost, price and return) is the differences between their expected outcomes when participating and the expected outcomes if they did not participate in the contract scheme. Hence, ATT can be displayed as:

$$
A T T=E\left(Y_{1}-Y_{0} \mid X, P=1\right)=\mathrm{E}\left(\mathrm{Y}_{1} \mid X, P=1\right)-\mathrm{E}\left(\mathrm{Y}_{\mathrm{o}} \mid X, P=1\right)
$$

Where ATT denotes the average effect of participation in contract farming on rice growers' outcomes (yield, price and return). $\mathrm{X}$ is a vector of observed characteristics of household that may affect the decision making to participating in the contract scheme and/or the expected outcome of farmers and used as explanatory variables. $\mathrm{P}$ denotes participation in a contract scheme $(\mathrm{P}=1$, if farmer participates in the contract scheme, and $\mathrm{P}=0$ otherwise).

The problem arising when estimating ATT given Equation (1), is that it could not be measured $\mathrm{E}\left(\mathrm{Y}_{0} \mid X, P=1\right)$ since this is unobserved. The fact is that it could not be observed simultaneously the outcome produced in case of nonparticipation for the same person who actually participated in the scheme. This problem may be solved by replacing unobserved outcome values (missing) of contract farmer $\mathrm{E}\left(\mathrm{Y}_{0} \mid X, P=1\right)$ with the expected 
outcome values of matched noncontract farmer who has similar observable characteristics to the contract farmer $\mathrm{E}\left(\bar{Y}_{0} \mid X, P=0\right)$ called counterfactual outcome. Therefore, equation (1) can be re-written as:

$$
A T T=E\left(Y_{I^{-}} Y_{0} \mid X, P=1\right)=\mathrm{E}\left(\mathrm{Y}_{1} \mid X, P=1\right)-\mathrm{E}\left(\bar{Y}_{0} \mid X, P=0\right)
$$

To ensure the similarity of characteristics in a dimension, the vector $\mathrm{X}$ could be condensed as the propensity score (Ito et al., 2012), which is the individual probability of taking the participation given the observable variables. Consequently, Equation (2) was used to estimate the effect of contract farming on rice growers' outcomes (yield, price and return) on the propensity score. To use a PSM for ATT estimates, two important assumptions must be satisfied. The first condition is conditional independence assumption (CIA) of expected outcomes and selection into the treatment given observable variables (Imbens, 2004). In other words, all variables that influence treatment assignment and expected outcomes must be observed (Caliendo and Kopeinig, 2008). The second is the overlap condition or the common support, which ensures that for each treated subject there are control subjects with the same observable covariates (Nannicini, 2007).

To measure ATT using PSM approach in the study, a five-steps procedure adopted by Wendimu et al. (2016) was used. The five-step process involves: (1) selection the variables that are used for matching; (2) choice of the matching algorithm; (3) estimating the propensity scores and matching based on the estimated propensity score; (4) checking and testing the balance for covariates before and after matching; and (5) estimating the effects from the matched data.

\subsection{Covariate selection and matching techniques}

Observable covariates influencing both participation selection and outcomes (yield, price and return, in this case) and not influenced by the participation should be selected from the sample for propensity score estimation using probit (or logit) model (Austin, 2011; Caliendo and Kopeinig, 2008; Maertens and Swinnen, 2009; Smith and Todd, 2005). Furthermore, the main purpose of estimating propensity score is to create good matches, not to predict participation selection in a contract scheme (Girma and Gardebroek, 2015). Therefore, ten variables were selected in this study such as age, education, experience, number of family member, rice area, social participation, boat ownership, and ownerships of storage, tractor and combine harvester. These covariates were included in the probit model for propensity score estimates. Selection of these variables was based on earlier empirical studies such as those by Maertens and Swinnen (2009), Maertens and Velde (2017), Mishra et al. (2018) and evidence from the survey. The details of these covariates are displayed in Table 2.

Once propensity scores are derived, ATT can be calculated by matching each contract participant to nonparticipant with similar propensity score value. There are several matching techniques proposed by Caliendo and Kopeinig (2008). In this study the nearest neighbor matching (NNM) and kernel matching (KM) were used to match participants and nonparticipants with conditioning on propensity score; because these matching techniques are the most common uses (Becerril and Abdulai, 2010). The former uses the individual household in the control group as a matching partner for a treated individual household that has closest propensity score, thus reducing bias; while the latter uses weighted averages of all individuals in control group to construct the counterfactual outcomes and yields low variance due to using all information from the controls (Caliendo and Kopeinig, 2008). The weights are the inverse proportion to the distance between propensity scores of treated and untreated groups (Becerril and Abdulai, 2010). Hence, the two matching techniques seem to be complementary.

\subsection{Matching quality assessment}

To check the quality of matching process, there are several tests proposed by Caliendo and Kopeinig (2008). In this study, the variables used to generate the propensity scores were compared before and after matching with focusing on quality of mean values using $t$-tests, a standardized bias reduction, and pseudeo- $\mathrm{R}^{2}$ value of the probit model. The literature showed that there should be no significantly systematical differences 
remaining for covariates between the treatment and control groups after matching on the propensity score (Caliendo and Kopeinig, 2008). Stuart and Rubin (2007) argued that the mean absolute standardized difference in the matched samples should be less than $25 \%$, an important indicator that the matching procedure has succeeded. Additionally, the pseudo- $\mathrm{R}^{2}$ showing how well the regressors explaining the probability of contract participation from the propensity score estimation should be relatively low after matching, because there are generally no systematic differences in the covariate distributions between the two groups (Maertens and Velde, 2017).

Additionally, the robustness of results obtained under the CIA was tested using a simulation - based sensitivity analysis proposed by (Nannicini, 2007) and applied in previous empirical studies such as Maertens and Swinnen (2009), and Maertens and Velde (2017). This method assumes that CIA holds given observed variable and unobserved binary confounder U. Hence, once $U$ is not observed, the outcome of the controls cannot be used to estimate the counterfactual outcome of the treated (Nannicini, 2007). In this study, dummy confounder was simulated to mimic possible unobserved factors influencing both outcome and selection and compared these PSM estimates with baseline results (no simulated confounder).

\section{Empirical results and discussion}

\subsection{Propensity score estimation}

Table 3 reports the results of binary probit regression model for estimating the propensity score or probability of contract participation. There were four variables significantly associated with participation in contract farming. Specifically, family size and membership in farmer-based organizations were positively associated with participation in contract farming scheme. Households with a larger number of members have a higher probability of participating in the contract scheme. This reflects the fact that contract farming may be more labor-intensive as compared to independent farms (Miyata et al., 2009). Farmers who have participated in farmer-based organizations are more likely to become a contract grower since they tend to be more accessible by enterprises. Furthermore, farmers being a member of their organization are encouraged and mobilized to contracting by the local and central governments. On the contrary, rice land area and storage ownership were negatively associated with the probability of participation in the contract scheme. This result suggests that

Table 3. Propensity score for contract farming participation. ${ }^{1}$

\begin{tabular}{lcccc}
\hline Variable & Coefficient & Std. Err. & z & $P$-value \\
\hline Age of household head (years) & 0.0089 & 0.0149 & 0.60 & 0.550 \\
Experience in rice farming (years) & 0.0106 & 0.0149 & 0.71 & 0.475 \\
Education of head (years of schooling) & 0.0447 & 0.0376 & 1.19 & 0.234 \\
Household size (persons) & 0.2613 & 0.0979 & 2.67 & $0.008^{* * *}$ \\
Rice land area (ha) & -0.1128 & 0.0680 & -1.66 & $0.097^{*}$ \\
Boat ownership (yes=1, otherwise=0) & 0.0969 & 0.2275 & 0.43 & 0.670 \\
Storage ownership (yes=1, otherwise=0) & -1.6505 & 0.8564 & -1.93 & $0.054^{*}$ \\
Harvester ownership (yes=1, otherwise=0) & 1.2526 & 1.0570 & 1.19 & 0.236 \\
Tractor ownership (yes=1, otherwise=0) & -0.3938 & 0.5884 & -0.67 & 0.503 \\
Social participation (yes=1, otherwise=0) & 0.4285 & 0.2575 & 1.66 & $0.096^{*}$ \\
Constant & -2.2660 & 0.7513 & -3.02 & $0.003^{* * *}$ \\
\hline Log likelihood & -100.5342 & & & \\
LR chi ${ }^{2}(10)$ & 24.97 & & & \\
Prob $>$ chi & & & & \\
Pseudo- ${ }^{2}$ & 0.0054 & & & \\
Number of observation & 0.1105 & & & \\
\hline l $^{*}$ & 166 & & & \\
\hline
\end{tabular}

$1^{*}$ and ${ }^{* * *}$ denote significance at $10 \%$ and $1 \%$ levels, respectively. 
farmers who have a large rice area and storage facility seem not to prefer contracting because the evidences from the investigation indicate that these farmers may have more choice of market channel with a better selling price as a result of large volume of output. Similarly, farmers with storage can store their paddy to avoid huge supply for rice during the peak harvest period, which may cause price falling during that time.

However, the results from the probit model showed that other covariates such as age, education and ricefarming experience of the household head, and ownerships of boat, harvester and tractor were unlikely to associate with the participation in the contract scheme. Generally, these results reflect the fact that there is some self-selection bias among rice growers to participate in the contract scheme. In other words, becoming a contract farmer is more likely to relate to a number of household members, rice land area, storage ownership, and a member of farmer-based organizations rather than age, experience, education of household head, and ownerships of boat, harvester and tractor.

\subsection{Matching quality}

Before discussing estimated effects of contract farming in rice crop, the quality of matching was taken into consideration since the propensity scores derived from the probit model were used for matching contract participants to nonparticipants. Figure 1 depicts the distribution of the propensity score and the area of common support. The figure showing the bias in the propensity score distribution between the treated and untreated groups reveals a sufficient region of the overlap condition to avoid bad matches. Table 4 reports the results of the balancing tests for the NNM and KM methods. By considering balancing properties, the equality of means between the treated and untreated groups was tested. These balancing tests showed that there were significant differences in mean values of a half of the covariates before matching between the treated and control groups but these differences were eliminated dramatically after matching, the smallest $P$-value from the $t$-tests after matching was 0.381 . Furthermore, balancing power is also taken into account when looking at the reduction in the mean absolute standardized bias between the matched and unmatched samples.

The results in Table 5 showed that the mean standardized bias for all confounding covariates after matching was $3.8 \%$ and $5.2 \%$ for KM and NNM, respectively, which lead to a reduction of around $77 \%$ in total bias. Table 5 also presents that the pseudo- $\mathrm{R}^{2}$ values were fairly low (all close to zero) and likelihood-ratio tests of the joint regressors were statistically insignificant, which revealed that there were no systematically

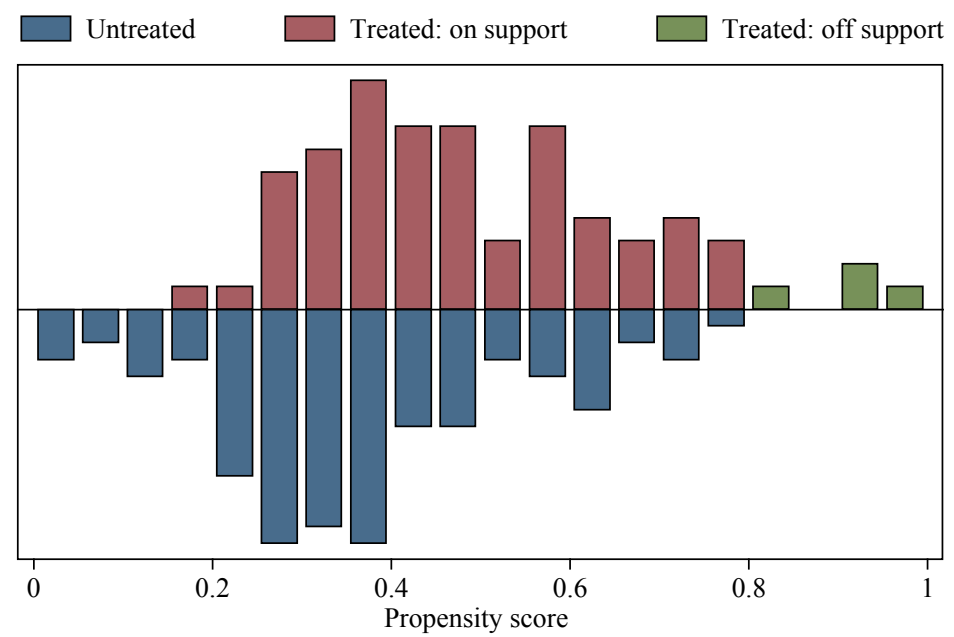

Figure 1. Propensity score distribution and common support propensity score estimation.

'Treated: on support' and 'Treated: off support' showing the observations in the treated group display consistent comparison and inconsistent comparison, respectively. 
Table 4. Covariates balancing test and bias reduction. ${ }^{1,2}$

\begin{tabular}{|c|c|c|c|c|c|c|}
\hline Variable & & Treated & Control & $\%$ bias & $\begin{array}{l}\% \text { bias } \\
\text { reduction }\end{array}$ & $P$-value \\
\hline \multirow[t]{3}{*}{ Age of household head (years) } & Unmatched & 52.429 & 48.438 & 35.9 & & $0.023^{* *}$ \\
\hline & NN. matched & 52.429 & 51.886 & 4.9 & 86.4 & 0.768 \\
\hline & K. matched & 51.636 & 51.164 & 4.3 & 88.2 & 0.803 \\
\hline \multirow[t]{3}{*}{ Experience in rice farming (years) } & Unmatched & 27.400 & 23.688 & 33.9 & & $0.028^{* *}$ \\
\hline & NN. matched & 27.400 & 26.521 & 8.0 & 76.3 & 0.625 \\
\hline & K. matched & 26.576 & 26.232 & 3.1 & 90.7 & 0.852 \\
\hline \multirow{3}{*}{$\begin{array}{l}\text { Education of head } \\
\text { (years of schooling) }\end{array}$} & Unmatched & 6.714 & 6.063 & 22.7 & & 0.147 \\
\hline & NN. matched & 6.714 & 6.605 & 3.8 & 83.2 & 0.822 \\
\hline & K. matched & 6.530 & 6.569 & -1.3 & 94.1 & 0.938 \\
\hline \multirow[t]{3}{*}{ Household size (persons) } & Unmatched & 4.871 & 4.385 & 39.6 & & $0.011^{* *}$ \\
\hline & NN. matched & 4.871 & 4.686 & 15.1 & 61.8 & 0.391 \\
\hline & K. matched & 4.697 & 4.618 & 6.4 & 83.8 & 0.693 \\
\hline \multirow[t]{3}{*}{ Rice land area (ha) } & Unmatched & 1.913 & 2.388 & -27.6 & & $0.094^{*}$ \\
\hline & NN. matched & 1.913 & 1.790 & 6.6 & 76.1 & 0.589 \\
\hline & K. matched & 1.968 & 1.780 & 11.0 & 60.4 & 0.381 \\
\hline \multirow{3}{*}{$\begin{array}{l}\text { Boat ownership } \\
(\text { yes }=1 \text {, otherwise }=0)\end{array}$} & Unmatched & 0.571 & 0.583 & -2.4 & & 0.879 \\
\hline & NN. matched & 0.571 & 0.614 & -8.6 & -260 & 0.609 \\
\hline & K. matched & 0.591 & 0.609 & -3.6 & -50.1 & 0.836 \\
\hline \multirow{3}{*}{$\begin{array}{l}\text { Storage holding } \\
(\text { yes }=1 \text {, otherwise }=0)\end{array}$} & Unmatched & 0.014 & 0.063 & -25.2 & & 0.128 \\
\hline & NN. matched & 0.014 & 0.012 & 1.2 & 95.1 & 0.902 \\
\hline & K. matched & 0.016 & 0.011 & 2.3 & 90.9 & 0.826 \\
\hline \multirow{3}{*}{$\begin{array}{l}\text { Harvester ownership } \\
(\text { yes }=1 \text {, otherwise }=0)\end{array}$} & Unmatched & 0.014 & 0.010 & 3.5 & & 0.823 \\
\hline & NN. matched & 0.014 & 0.012 & 2.1 & 38.5 & 0.902 \\
\hline & K. matched & 0.015 & 0.011 & 3.9 & -12.9 & 0.826 \\
\hline \multirow{3}{*}{$\begin{array}{l}\text { Tractor ownership } \\
(\text { yes }=1 \text {, otherwise }=0)\end{array}$} & Unmatched & 0.029 & 0.052 & -11.9 & & 0.460 \\
\hline & NN. matched & 0.029 & 0.029 & 0.0 & 100 & 1.000 \\
\hline & K. matched & 0.030 & 0.028 & 0.9 & 92.1 & 0.950 \\
\hline \multirow{3}{*}{$\begin{array}{l}\text { Social participation } \\
(\text { yes }=1 \text {, otherwise }=0)\end{array}$} & Unmatched & 0.300 & 0.177 & 29.0 & & $0.063^{*}$ \\
\hline & NN. matched & 0.300 & 0.276 & 5.6 & 80.6 & 0.758 \\
\hline & K. matched & 0.273 & 0.254 & 4.5 & 84.6 & 0.807 \\
\hline
\end{tabular}

${ }^{1} \mathrm{NN}$ : nearest neighbour, K: kernel.

$2{ }^{*}$ and ${ }^{* *}$ denote significance at $10 \%$ and $5 \%$ levels, respectively.

Table 5. Propensity score matching quality indicators before and after matching and sensitivity analysis. ${ }^{1}$

\begin{tabular}{llllllll}
\hline $\begin{array}{l}\text { Matching } \\
\text { methods }\end{array}$ & $\begin{array}{l}\text { Pseudo } \\
\mathbf{R}^{2} \text { before } \\
\text { matching }\end{array}$ & $\begin{array}{l}\text { Pseudo } \\
\mathbf{R}^{2} \text { after } \\
\text { matching }\end{array}$ & $\begin{array}{l}\boldsymbol{P}>\mathbf{C h i}^{2} \\
\text { before } \\
\text { matching }\end{array}$ & $\begin{array}{l}\boldsymbol{P}>\mathbf{C h i}^{2} \text { after } \\
\text { matching }\end{array}$ & $\begin{array}{l}\text { Mean } \\
\text { standardized } \\
\text { bias before } \\
\text { matching }\end{array}$ & $\begin{array}{l}\text { Mean } \\
\text { standardized } \\
\text { bias after } \\
\text { matching }\end{array}$ & $\begin{array}{l}\% \mid \text { bias } \mid \\
\text { reduction }\end{array}$ \\
\hline $\mathrm{KM}$ & 0.110 & 0.006 & 0.005 & 1.000 & 26.4 & 3.8 & 77.6 \\
$\mathrm{NNM}$ & 0.110 & 0.009 & 0.005 & 0.998 & 26.4 & 5.2 & 77.6 \\
\hline
\end{tabular}

${ }^{1} \mathrm{KM}$ : kernel matching, NNM: nearest neighbour matching. 
significant differences in the distribution of covariates between the treated and control groups after matching. The implication of these results suggests that there was an existing bias for the covariates but using the matching methods eliminated this bias, and all covariates after matching are more likely to be satisfied. Therefore, the ATT can be consistently estimated (Rosenbaum and Rubin, 1985).

\subsection{Estimated effect of contract farming}

Table 6 shows estimated effect of contract participation on outcomes of rice growers per one hectare in one crop (yield, cost, and average return) and output price using the NNM and KM methods. The effect estimation results in Table 2 using both matching techniques appeared similar. It was found that participation in a contract scheme had no effects on rice yield for the sampled farmers. While previous studies showed that contract farming remarkably increased crop yield (Maertens and Velde, 2017; Mishra et al., 2018; Miyata et al., 2009). Similarly, participation in the contract scheme is likely to result in decreasing production cost but the reduction was not significant. This result is supported by a study by Mishra et al. (2018) but a study by Maertens and Velde (2017) revealed that contract farming lead to a major increase in production cost of rice cultivation in Benin.

However, the causal effect of contract farming participation on selling price for rice was positive and statistically significant at the 5\% level, with an increase ranging between 5.6 and 5.9 USD per ton of rice for KM and NNM, respectively. This result is consistent with the findings from Maertens and Velde (2017), Girma and Gardebroek (2015), and Miyata et al. (2009). The possible explanation for higher-selling price may be that the quality of output produced by contracting farmers under the supervision of a contract firm could be better than that by other farmers. As a result of a substantial increase in output price, contract participants earned a larger return in rice production or crop income by approximately between $7 \%$ and $8 \%$ for KM and NNM, respectively, which suggest that contract farming returns may increase by around 68 USD per hectare. This finding is in line with earlier studies by Bolwig et al. (2009), Birthal et al. (2008), $\mathrm{Hu}$ (2013), Mishra et al. (2018), Maertens and Velde (2017), Naryananan (2014), and Simmon et al. (2005). Specifically, Jones and Gibbon (2011) found that farmers who entered into cocoa contract farming increase their profit by about 58\% compared to non-participants. Overall, these findings suggest that contract farming carried out by domestically private and exporting enterprises has a positive impact on output price and return for rice farmers in the study area.

Table 6. Estimated effect of contract farming on profitability performance. ${ }^{1,2}$

\begin{tabular}{llllc}
\hline Outcome $^{\mathbf{3}}$ & Matching methods & ATT & Std. Err. & $\boldsymbol{t}$-value \\
\hline Yield (kg per ha) & NNM & 36 & 177 & 0.20 \\
& KM & 46 & 172 & 0.27 \\
Variable costs (USD per ha) & NNM & -18.086 & 14.033 & -1.29 \\
& KM & -18.579 & 13.772 & -1.35 \\
Output price (USD per ton) & NNM & 5.866 & 2.488 & $2.37^{* *}$ \\
& KM & 5.644 & 2.400 & $2.33^{* *}$ \\
Average return (USD per ha) & NNM & 68.933 & 38.888 & $1.77^{*}$ \\
& KM & 67.511 & 38.755 & $1.74^{*}$ \\
\hline
\end{tabular}

${ }^{1}$ KM: kernel matching, NNM: nearest neighbour matching.

$2 *$ and $^{* *}$ denote significance at $10 \%$ and $5 \%$ levels, respectively

${ }^{3} 1 \mathrm{USD}$ is taken here as $22,500 \mathrm{VND}$ at the time of the survey 


\subsection{Sensitivity analysis}

Table 7 shows the results of simulation-based sensitivity analysis using KM. Three types of confounders U were used, firstly, a neutral confounder $U_{n}$, the confounder with probabilities $p_{i j}=0.5$ with treatment $T=i$ ( $\mathrm{i}=1$ or 0 ) and outcome $\mathrm{Y}=\mathrm{j}(\mathrm{j}=1$ or 0 ), is able to perturb the baseline estimate (Ichino et al., 2008). Secondly, a 'killer' confounder $\mathrm{U}_{\mathrm{k}}$ with probabilities $\mathrm{p}_{11}=0.8, \mathrm{p}_{10}=0.6, \mathrm{p}_{01}=0.4, \mathrm{p}_{00}=0.3$, having both strong effects on selection and outcome, displays a worst-case situation relating to the CIA validity (Nannicini, 2007). Finally, a 'calibrated' confounder that mimics social participation variable $\mathrm{U}_{\mathrm{sp}}$ is a dummy variable which may highly influence both selection and outcome (Nannicini, 2007; Ichino et al., 2008).

The results in Table 7 reported that deviation of estimates with $U_{n}$ was less than $4 \%$ compared to the baseline estimates, with $\mathrm{U}_{\mathrm{k}}$ less than $10 \%$ and $\mathrm{U}_{\mathrm{sp}}$ less than $35 \%$. These numbers imply that the presence of confounder $U_{n}, U_{k}$ and $U_{s p}$ among unobserved factors can explain less than $4 \%, 10 \%$ and $35 \%$ of the baseline estimates, respectively. These results revealed that the estimated effect of contract participation on rice yield was the least robust, while the impacts on variable cost, output price and return were likely the most robust. Generally, when simulating the confounder U, even with the 'killer' confounder, the estimates were relatively closed to the original estimates. It might be concluded that the results of estimated effects by the PSM were plausible and did not violate the CIA assumption.

Table 7. Simulation-based sensitivity analysis for propensity score matching estimates. ${ }^{1,2,3}$

\begin{tabular}{llcclc}
\hline & & $\begin{array}{l}\text { Yield } \\
\text { (kg per ha) }\end{array}$ & $\begin{array}{l}\text { Cost } \\
\text { (USD per ha) }\end{array}$ & $\begin{array}{l}\text { Output price } \\
\text { (USD per ton) }\end{array}$ & $\begin{array}{l}\text { Return } \\
\text { (USD per ha) }\end{array}$ \\
\hline No simulated confounder & Baseline ATT & 22.37 & -22.982 & 5.964 & 67.271 \\
Neutral confounder $\mathrm{U}_{\mathrm{n}}{ }^{4}$ & ATT & 20.66 & -22.198 & 5.898 & 68.056 \\
& Outcome effect & 1.028 & 1.098 & 1.174 & 1.153 \\
& Selection effect & 1.069 & 1.089 & 1.092 & 1.051 \\
'Killer' confounder $\mathrm{U}_{\mathrm{k}}{ }^{5}$ & ATT & 20.48 & -24.165 & 5.501 & 60.806 \\
& Outcome effect & 1.152 & 1.835 & 1.816 & 1.639 \\
& Selection effect & 5.549 & 5.680 & 8.161 & 5.468 \\
Confounder to mimic social & ATT & 14.82 & -21.674 & 5.839 & 60.667 \\
participation $\mathrm{U}_{\mathrm{sp}}{ }^{6}$ & Outcome effect & 5.064 & 1.095 & 1.766 & 2.380 \\
& Selection effect & 2.034 & 2.349 & 2.259 & 2.154 \\
\hline
\end{tabular}

${ }^{1}$ Outcome effect measures the effect of the binary confounder on the untreated outcome.

${ }^{2}$ Selection effect measures the effect of the binary confounder on the probability of selection into treatment.

${ }^{3}$ USD is taken here as 22,500 VND at the time of the survey.

${ }^{4} U_{n}$ set with probabilities of Treatment $(T)$ and Outcome $(Y): p(T=1 ; Y=1)=0.5 ; p(T=1 ; Y=0)=0.5 ; p(T=0 ; Y=1)=0.5 ; p(T=0 ; Y=0)=0.5$.

${ }^{5} \mathrm{U}_{\mathrm{k}}$ set with probabilities of Treatment $(\mathrm{T})$ and Outcome $(\mathrm{Y})$ : $\mathrm{p}(\mathrm{T}=1 ; \mathrm{Y}=1)=0.8 ; \mathrm{p}(\mathrm{T}=1 ; \mathrm{Y}=0)=0.6 ; \mathrm{p}(\mathrm{T}=0 ; \mathrm{Y}=1)=0.4 ; \mathrm{p}(\mathrm{T}=0 ; \mathrm{Y}=0)=0.3$.

${ }^{6} \mathrm{U}_{\mathrm{sp}}$ : dummy variable. 


\section{Conclusions}

This study can be seen as the first effect estimation of private-led contract farming on rice farmers' yield, cost, selling price and return in Vietnam's Mekong Delta using different propensity-score matching techniques to adjust the selection bias. The findings reveal that contract farming has a positive impact on the output price and the average return for small rice growers in the study area, but has no significant effect on yield and variable cost. Generally, these suggest that this scheme may increase both rice and household incomes for these farmers since their incomes are mostly derived from rice cultivation. Expanding contract farming in the rice sector is likely an effective tool to reach the target of the Vietnamese government for increasing the quality of rice, and rice growers' income. Notably, Miyata et al. (2009) contended that although contract farming is likely to have highly positive effects on increasing small-farm income, it may only apply in certain contexts.

In relation to policy recommendations, the findings from the study recommend that contract farming may be unfeasible for all rice growers and business firms, because several firms cannot provide inputs (e.g. seed and agrochemicals), and technical assistance to their contract growers due to their human and financial limitations. Meanwhile, some farmers, particularly farmers with large-scale farm, are less likely to participate in a contract scheme in the study area, because they seemingly have more market outlet choices that can sometimes help them to gain a greater selling price for rice, leading a considerable increase in total return. Thus, the possible argument may be that the government should not force all rice farmers as well as rice business firms to engage in the contract scheme and should focus on providing supporting policy regarding sustainable operation of contract farming rather than its scope.

As earlier mentioned, this paper is considered the first study which took into account bias selection with PSM method as estimating the impact of contract farming on the rice crop's outcomes in the Mekong Delta. The impact estimation by PSM still remains shortcomings such as unobservable attributes of households not included in the regression model. A further study should cover unobserved variables in estimation model by other econometric approaches such as instrumental variable analysis and switching regression model. Investigating larger sample size in various study locations with different schemes of contract and rice crops over time should be considered in the future studies.

\section{References}

Aakvik, A. 2001. Bounding a matching estimator: the case of a Norwegian training program. Oxford Bulletin of Economics and Statistics 63: 115-143.

Austin, P.C. 2011. An introduction to propensity score methods for reducing the effects of counfouding in observational studies. Multivariate Behavioral Research 46: 399-424.

Barrett, C.B., M.E. Bachke, M.F. Bellemare, H.C. Michelson, S. Narayanan and T.F. Walker. 2012. Smallholder participation in contract farming: comparative evidence from five countries. World Development 40 (4): 715-730.

Becerril, J. and A. Abdulai. 2010. The impact of improved maize varieties on poverty in Mexico: a propensity score-matching approach. World Development 38 (7): 1024-1035.

Bellemare, M.F. 2012. As you sow, so shall you reap: the welfare impacts of contract farming World Development 40 (7): 1418-1434.

Birthal, P.S., A.K. Jha, M.M. Tiongco and C. Narrod. 2008. Improving farm-to-market linkages through contract farming: a case study of smallholder dairying in India. Discussion Paper 00814. International Food Policy Research Institute, Washington DC, USA.

Bolwig, S., P. Gibbon and S. Jones. 2009. The economics of smallholder organic contract farming in tropical Africa. World Development 37 (6): 1094-1104.

Cahyadi, E.R. and H. Waibel. 2013. Is contract farming in the Indonesian oil palm industry pro-poor? Journal of Southeast Asian Economies 30 (1): 62-69. 
Caliendo, M. and S. Kopeinig. 2008. Some practical guidance for the implementation of propensity score matching. Journal of Economic Surveys 22 (1): 31-72.

Can, N.D. 2014. Understanding 'linking together four houses' in rice production and commerce: a case study of An Giang province, Vietnam and lesson learnt from Chiba prefecture, Japan. JETRO, Chiba, Japan.

Da Silva, C.A. 2005. The growing role of contract farming in agri-food systems development: driver, theory and practice. Food and Agriculture Organization of the United Nations, Rome, Italy.

Dung, L.N.T, Nam, M.V. 2015. Analysis of the financial performance of rice producing households in the model associated with the enterprise in An Giang Province. Can Tho University Journal of Science 36: $92-100$.

Eaton, C. and A. Shepherd. 2001. Contract farming: partnership for growth. Bulletin 165. Food and Agriculture Organization of the United Nations, Rome, Italy.

FAO, 2016. Rice market monitor. Food and Agriculture Organization of the United Nations, Rome, Italy.

Girma, J. and C. Gardebroek. 2015. The impact of contracts on organic honey producers' incomes in southwestern Ethiopia. Forest Policy and Economics 50: 259-268.

Glover, D. 1990. Contract farming and outgrow schemes in East and Southern Africa. Journal of Agricultural Economics 41 (2): 303-315.

GSO (General Statistic Office). 2016. Statistical Yearbook of Vietnam. Statistical Publishing House, Hanoi, Vietnam.

GSO (General Statistics Office). 2017. Summary report of the 2016 rural, agriculture and fishery census. Statistical Publishing House, Hanoi, Vietnam.

Gulati, A., N. Minot, C. Delgado and S. Bora. 2007. Growth in high value agriculture in Asia and the emergence of vertical links with farmers. In: Global supply chain, standards, and poor farmers, edited by J. Swinnen. CAB International, London, UK, pp.91-108.

Hu, W.Y. 2013. Effect of contract farming on the U.S. crop farmers' average return. Agricultural EconomicsCzech 59 (5): 195-201.

Ichino A., F. Mealli and T. Nannicini. 2008. From temporary help jobs to permanent employment: what can we learn from matching estimators and their sensitivity? Journal of Applied Economics 23 (3): 305-327.

Imbens, G.W. 2004. Nonparametric estimation of average treatment effects under exogeneity: a review. The Review of Economics and Statistics 86 (1): 4-29.

Ito, J., Z. Bao and Q. Su. 2012. Distributional effects of agricultural cooperatives in China: exclusion of smallholders and potential gains on participation. Food Policy 37 (6): 700-709.

Jaffee, S. 2003. From challenge to opportunity: the transformation of the Kenyan fresh vegetable trade in the context of emerging food safety and other standards. PREM Trade Unit, World Bank, Washington DC, USA.

Jalan, J. and M. Ravallion. 2003. Estimating the benefit incidence of antipoverty program by propensityscore matching. Journal of Business and Economic Statistics 21 (1): 19-30.

Jones, S. and P. Gibbon. 2011. Developing agricultural markets in Sub-Sahara Africa: organic cocoa in rural Uganda. Journal of Development Studies 47 (10): 1595-1618.

Little, P. and M. Watts. 1994. Living under contract: contract farming and agrarian transformation in SubSaharan Africa. The University of Wisconsin Press, Madison, USA.

Loc, N.T.T. and N.P. Son. 2011. Value chain analysis of rice product in the Mekong Delta. Can Tho University Journal of Science 19: 96-108.

Maertens, M. and J.F.M. Swinnen. 2009. Trade, standards and poverty: evidence from Senegal. World Development 37 (1): 161-178.

Maertens, M. and K.V. Velde. 2017. Contract-farming in staple food chains: the case of rice in Bennin. World Development 95: 73-87.

Minot, N. 1986. Contract farming and its effect on small farmers in less-developed countries. Working Paper No. 31. Michigan State University, Michigan, USA. 
Minot, N. and B. Sawyer. 2016. Contract farming in developing countries: theory, practice and policy implications. In: Innovation for inclusive value-chain development: successes and challenges, edited by A. Devaux, M. Toreto, J. Donovan and D. Horton. International Food Policy Research, Washington, D.C., USA, pp.127-155.

Mishra, A.K, A. Kumar, P.K. Joshi and A. D'Souza. 2018. Impact of contract farming on yield, cost and profitability in low-value crop: evidence from a low-income country. The Australia Journal of Agricultural and Resource Economics 62: 589-607.

Miyata, S., N. Minot and D. Hu. 2009. Impact of contract farming on income: Linking small farmers, packers, and supermarkets in China. World Development 37 (11): 1781-1790.

Nannicini, T. 2007. Simulation-based sensitivity analysis for matching estimators. The Stata Journal 7 (3): 334-350.

Naryananan, S. 2014. Profits from participation in high-value agriculture: Evidence from heterogeneous benefits in contract farming schemes in Southern India. Food Policy 44: 142-157.

Nhan, T.Q. and T. Yutaka. 2017. Current status and problems of rice contract farming enforcement in Mekong Delta, Vietnam. Agricultural Marketing Journal of Japan 26 (1): 43-50.

Nhan, T.Q. and T. Yutaka. 2018. Analysis of contract farming between paddy farmers and an agribusiness in the Mekong Delta of Vietnam. Agricultural Marketing Journal of Japan 27 (1): 60-67

Oanh, L.T.K., B.T. Nga and P. Lebailly. 2016. Tea production between contract and noncontract farmers in Phu Tho province, Vietnam. Scholars Journal of Agriculture and Veterinary Sciences 3 (2): 117-122.

Porter, G. and K. Phillips-Howard. 1997. Comparing contracts: an evaluation of contract farming schemes in Africa. World Development 25 (2): 227-238.

Reardon, T., C.B. Barrett and J.A. Berdegue'. 2009. Agrifood industry transformation and small farmers in developing countries. World Development 37 (11): 1717-1727.

Rosenbaum, P.R. and D.B. Rubin. 1983. The central role of the propensity score in observational studies for causal effects. Biometrika 70 (1): 41-55.

Rosenbaum, P.R. and D.B. Rubin. 1985. Constructing a control group using multivariate matched sampling methods that incorporate the propensity score. American Statistician 39 (1): 33-38.

Saenger, C., M. Qaim, M. Torero and A. Viceisza. 2013. Contract farming and smallholder incentives to produce high quality: experimental evidence from the Vietnamese dairy sector. Agricultural Economics 44 (3): 297-308.

Simmon, P., P. Winters and I. Patrick. 2005. An analysis of contract farming in East Java, Bali, and Lombok, Indonesia. Agricultural Economics 33 (s3): 513-552.

Singh, S. 2002. Contract farming out solutions: political economy of contract farming in the Indian Junjab. World Development 30 (9): 1621-1638.

Smith, J.A. and P.E. Todd. 2005. Does matching overcome LaLonde's critique of nonexperimental estimators? Journal of Econometrics 125 (1-2): 305-353.

Stuart, E.A. and D.B Rubin. 2007. Best practices in quasi-experimental designs: matching methods for causal inference. In: Best practices in quantitative social science, edited by J. Osborne. Sage, Thousand Oaks, CA, USA, pp.155-176.

Swinnen, J.F.M. and M. Maertens. 2007. Globalization, privatization and vertical coordination in food value chains in developing and transition countries. Agricultural Economics 37 (1): 89-102.

Trifkovíc, N. 2014. Governance strategies and welfare effects: vertical integration and contracts in the catfish sector in Vietnam. Journal of Development Studies 50: 949-961.

Tuan, N.P. 2012. Contract farming and its impact on income and livelihoods for small-scale farmers: case study in Vietnam. Journal of Agribusiness and Rural Development 4 (26): 147-166.

Vinh, T.V., Dinh P.V. 2014. Some solutions for developing contract integration in production - consumption of rice in Dong Thap province. Journal of Science and Development 12 (6): 844-852.

Wainaina, P.W., J.J. Okello and J.M. Nzuma. 2014. Blessing or Evil? Contract farming, smallholder poultry production and household welfare in Kenya. Quarterly Journal of International Agriculture 53 (4): 319-340. 
Wang, H., P. Moustier and N.T.T. Loc. 2014. Economic impact of direct marketing and contracts: the case of safe vegetable chains in northern Vietnam. Food Policy 47: 13-23.

Warning, M. and N. Key. 2002. The social performance and distributional consequences of contract farming: an equilibrium analysis of the Arachide de Bouche program in Senegal. World Development 30 (2): 255-263.

Wendimu, M.A., A. Henningsen and P. Gibbon. 2016. Sugarcane outgrowers in Ethiopia: 'forced to retain poor? World Development 83: 84-97. 